\title{
Genotoxic effects of Tabebuia impetiginosa (Mart. Ex DC.) Standl. (Lamiales, Bignoniaceae) extract in Wistar rats
}

\author{
Odilon A. Lemos ${ }^{1}$, Júlio C.M. Sanches ${ }^{1}$, Ícaro E.F. Silva ${ }^{1}$, Márcio L.A. Silva ${ }^{1}$, Adriana H.C. Vinhólis ${ }^{1}$, \\ Mireille A.P. Felix ${ }^{1}$, Raquel A. Santos ${ }^{1}$ and Andréa O. Cecchi ${ }^{1}$ \\ ${ }^{1}$ Universidade de Franca, Franca, SP, Brazil.
}

\begin{abstract}
Tabebuia sp. is native to tropical rain forests throughout Central and South America. Although the biological and pharmacological effects of bark extracts have been intensely studied, little is known on the extract obtained from the flower. Herein, the genotoxic potential of a flower extract from T. impetiginosa ("ipê roxo") on the blood and liver cells of Wistar rats was evaluated. Experimental procedures involved only male animals. Graduated concentrations of the extract, viz., 100,300 and $500 \mathrm{mg} \mathrm{kg}^{-1}$ of body weight, were gavage-administered and $24 \mathrm{~h}$ latter cells were collected and processed for analysis. With the exception of the $100 \mathrm{mg} \mathrm{kg}^{-1}$ dose, a significant increase in DNA damage was noted, when compared with a negative control group. Although the genotoxic potential of this extract was higher in liver cells, the response in both tissues was related to dose-dependency. Even though DNA damage can be corrected before conversion into mutations, further study is recommended to arrive at a better understanding of incurred biological effects.
\end{abstract}

Key words: Tabebuia impetiginosa, comet assay, Wistar rats, natural compounds.

Received: September 26, 2011; Accepted: January 30, 2012.

\section{Introduction}

Over the centuries, plants have been the main source of crude drugs used in the cure or alleviation of human sicknesses (Skalani and Kutty, 2008). In America, herbal therapies, together with various other traditional remedies, are generally classified under the heading of "alternative medicine". The combination of this medical form, mainly involving the aforementioned traditional and folk remedies used worldwide, with conventional western medicine is termed "integrative medicine" (Itokawa et al., 2008).

Tabebuia spp. (Bignoniaceae) is a native of Tropical Rain Forests throughout Central and South America (Son et $a l ., 2006)$. Extracts from the bark of this plant are known as "taheebo", "lapacho", "pau d'arco" or "ipê". Their most important components include naftoquinones, quinines, furanonaftoquinones, bezoic acid, ciclopentenes dialdehydes and flavonoids (Sharma et al., 1988; Koyama et al., 2000). These extracts are traditionally used in the treatment of ulcers, syphilis, gastrointestinal problems, candidiasis, cancer, diabetes, prostatitis, constipation and allergies (Park et al., 2006). More recently, Melo et al. (2011) revised several of those medicinal plants employed in ethnobotanic research in Brazil that presented certain antitumor effects. Among the 84 studied, T. impetiginosa was the second

Send correspondence to Andréa de Oliveira Cecchi. Universidade de Franca, Av. Dr. Armando Sales de Oliveira n. 201, 14404-600 Franca, SP, Brazil. E-mail: andrea@unifran.br. most cited in ethnopharmocological literature, in the treatment or prevention of cancer and tumors (Melo et al., 2011).

Evidence on the biological effects of plant extracts is constantly on the increase. Nevertheless, their composition, apparently involving only beneficial properties, may include chemical components with mutagenic, teratogenic or carcinogenic activities (Santos et al., 2008). If a genotoxic compound is present, it is capable of interacting with DNA molecules, thereby leading to genetic damage in regions of fundamental importance for cycle-control and apoptosis, with the subsequent initiation of neoplastic processes (Santos et al., 2008). Whereby, the extreme importance of including a genotoxic approach in the toxicological evaluation of therapeutical compounds.

Numerous endpoints are commonly used in toxicological genetics. The alkaline version of Comet assaying, or rather Single Cell-Gel Electrophoresis (SCGE), represents a rapid, visual and quantitative technique for measuring DNA damage in eukaryote cells, such as single and double-strand breaks, as well as incomplete repair and alkali labile sites, and DNA-protein and DNA-DNA cross-links, in virtually any eukaryotic cell population obtainable as a single-cell suspension (Burlinson et al., 2007). Although this method is not included among the current genotoxicological tests recommended by the Organization for Economic Co-operation and Development (OECD), interna- 
tional expert groups have published recommendations describing standards for comet assaying based on the current OECD guidelines for other in vivo genotoxicity tests, such as MN assay (Tice et al., 2000; Hartmann et al., 2003).

Accordingly, in the present study, the genotoxic activities of a Tabebuia impetiginosa in vivo extract were assessed, using blood and liver cells from Wistar rats. The extent of DNA damage was detected through Comet assay.

\section{Material and Methods}

\section{Chemical compounds and extracts}

Normal melting point agarose, low melting point agarose, Ethylenediamine tetraacetic acid (EDTA), Tris base, ethidium bromide and dimethyl sulfoxide (DMSO) were all purchased from Sigma-Aldrich (St. Louis, MO, USA). Doxorubicin (DXR) was purchased from Pharmacia (Brazil, Ltda), for dissolution in distilled water, immediately preceding use as positive control.

The Tabebuia impetiginosa extract, kindly donated by the Chemical Research Group of the University of Franca, Franca, São Paulo State, Brazil, was dissolved in DMSO (10\% in distilled water) just prior to use. The inflorescences used in the preparation of the extract were collected from "ipê roxo" (T. impetiginosa Standl., Bignomiaceae) trees, in Franca. Drying in an air-circulating oven at $60{ }^{\circ} \mathrm{C}$ gave origin to $1.1 \mathrm{~kg}$ of dried material in powder form. After four weeks, $60.1 \mathrm{~g}$ of hydroalcoholic extract was obtained by macerating. This was refrigerator stored until use. On the occasion, the extract was dissolved in dimethyl sulfoxide (DMSO) at a concentration of $10 \%$ of the solution. The desired concentrations (100, 300 and $500 \mathrm{mg} \mathrm{kg}^{-1}$ per b.w. of the animal) were based on the dosage used in pertinent analgesic activity in rats, according to a project developed in the University (unpublished data).

\section{Animals and treatments}

Experiments with Wistar rats were carried out with the approval of the University of Franca Ethics Committee (process 007/07A). Thirty male Wistar rats, each weighing $100 \mathrm{~g}$, were acclimatized for 3 days prior to the experiments. Maintenance was under controlled conditions of temperature $\left(24 \pm 1^{\circ} \mathrm{C}\right)$ and humidity $(55 \pm 5 \%)$, in a $12: 12$ $\mathrm{h}$ light/dark cycle, with water and a commercial meal (Purina ${ }^{\circledR}$ ) ad libitum.

The experimental design comprised 6 groups treated for $24 \mathrm{~h}$ prior to euthanasia. Group 1 (negative control) mice received only drinking-water $(0.5 \mathrm{~mL}$ by gavage), Group 2 (positive control), a single injection of doxorubicin (90 mg kg-1 b.w., i.p.), Groups 3-5, treatment by gavage (0.5 mL) with solutions of T. impetiginosa extract (100, 300 and $500 \mathrm{mg} \mathrm{kg}^{-1}$ b.w., respectively), and Group 6 (solvent control), treatment by gavage $(0.5 \mathrm{~mL})$ with DMSO $10 \%$ $(\mathrm{v} / \mathrm{v})$ in distilled water. Euthanasia was by an overdose of thiopentone sodium (45 $\mathrm{mg} \mathrm{kg}^{-1}$ b.w.).

\section{Sample collection}

Blood samples were collected from the tail into heparinized microtubes. An aliquot of $10 \mu \mathrm{L}$ each was used for comet assaying. Immediately after collection, the animals underwent euthanasia. Liver cells, obtained by excising a single fragment (approximately $1 \mathrm{~g}$ ) from the right lobe, were washed in $\mathrm{NaCl}(0.9 \%)$ and minced in $1 \mathrm{~mL}$ of cold Hanks solution (pH 7.4, DMSO 10\% and EDTA $20 \mathrm{mM}$ ). Aliquots of $30 \mu \mathrm{L}$ of cell suspension were used in comet assaying. The samples, which were kept on ice as previously recommended (Collins et al., 2008), underwent trypan blue exclusion staining for cell viability.

\section{Comet assay}

Evaluation of the extent of DNA damage in both blood and liver cells was by way of the alkaline version of comet assaying (Singh et al., 1988). Briefly, the cell suspension was first homogenized with $100 \mu \mathrm{L}$ of low melting point agarose $(0.5 \%)$, then spread onto slides previously coated with normal melting point agarose $(1.5 \%)$, and finally covered with a coverslip. After $5 \mathrm{~min}$ at $4{ }^{\circ} \mathrm{C}$, the coverslip was removed, and the slides immersed in a cold lysis solution (2.4 M NaCl; $100 \mathrm{mM}$ EDTA; $10 \mathrm{mM}$ Tris, $10 \%$ DMSO and 1\% Triton-X, pH 10) for $24 \mathrm{~h}$. Subsequently, they were placed into an electrophoresis chamber and covered with an electrophoresis buffer $(300 \mathrm{mM} \mathrm{NaOH}$ per $1 \mathrm{mM}$ EDTA, $\mathrm{pH}>13$ ) for an additional $20 \mathrm{~min}$ in order to facilitate DNA unwinding. Electrophoresis proceeded for $20 \mathrm{~min}(1 \mathrm{~V} / \mathrm{cm}$ and $300 \mathrm{~mA})$ and the slides were then submerged for $15 \mathrm{~min}$ in neutralization buffer $(0.4 \mathrm{M}$ Tris$\mathrm{HCl}, \mathrm{pH} 7.5$ ), dried at room temperature and fixed in $100 \%$ ethanol for $5 \mathrm{~min}$. Slides were stained with $20 \mu \mathrm{g} / \mathrm{mL}$ ethidium bromide immediately before analysis and prepared in duplicate. 100 cells were screened per sample (50 from each slide) by means of a fluorescent microscope (Zeiss, Germany) equipped with an excitation filter of 515-560 nm, a barrier filter of $590 \mathrm{~nm}$ and a 40X objective. Nuclei were visually classified according to fragment migration, as follows: class 0 (no damage), class 1 (little damage, with tail-length less than the diameter of the nucleus), class 2 (medium damage, with tail-length one to two times the diameter of the nucleus), class 3 (significant damage with tail-length between two and a half to three times the diameter of the nucleus), and class 4 (very significant damage with tail-length more than three times the diameter of the nucleus). This scoring system was based on extensive recommendations in the literature (Tice et al., 2000; Collins et al., 2008; Liao et al., 2009).

\section{Statistical analysis}

Experimental data are expressed as means \pm SD of 5 animals. Differences among groups treated with different concentrations of $T$. impetiginosa in comparison to nega- 
tive and positive control were evaluated by Student-t testing with GraphPad Prism 4.1.

\section{Results}

The results obtained in blood cells of Wistar rats after $24 \mathrm{~h}$ of treatment with $T$. impetiginosa extract and the respective controls (negative and positive), appear in Table 1. Statistical analysis of significant differences between groups treated with the extract $\left(100,300\right.$ and $500 \mathrm{mg} \mathrm{kg}^{-1}$ b.w.) and the negative control ( $\mathrm{p}<0.05)$, indicated a dosedependent response.

DNA damage in nucleoids of liver cells was significantly higher in the groups treated with the extract than in the negative control $(\mathrm{p}<0.05)($ Table 2). Moreover, the response to treatment with $T$. impetiginosa was dosedependent. DNA damage was higher in the highest concentration tested $\left(500 \mathrm{mg} \mathrm{kg}^{-1}\right.$ b.w.) than in the positive control $(p<0.05)$. According to the DNA damage index, damage in the DMSO group, though higher than in the negative control, was not significantly so (Table 2). The distribution of comet nucleoids did not differ in any of the groups (negative control and DMSO) (Figure 1).
Distribution of the various levels of DNA damage observed in comet nucleoids is presented in Figure 1. The frequency of comet nucleoids at levels 2 and 3 was higher in the liver than in the blood. DNA damage in the blood at level 1 accounted for $50 \%$ of damaged nucleoids. Taken as a whole, in the liver, frequencies at levels 2, 3 and 4 were higher than at level 1.

\section{Discussion}

The active principles present in extracts from a variety of plant sources from tropical and sub-tropical regions of the world, have been studied for their possible application in human-health treatment (Aruoma, 2003). For many years, stem-bark of the South American tree Tabebuia impetiginosa has been extensively used in both North and South America as an anticancer, antifungal, antibacterial and anti-inflammatory drug (Abbott et al., 1967; Zani et al., 1991).

Genotoxicity assaying is a means of evaluating the capacity of different compounds to induce genetic damage, such as single- and double-strand breaks, chromosomal aberrations and genetic mutations. This can be done in vitro or

Table 1 - Distribution of comet cells (mean \pm SD) and DNA damage index in blood cells of Wistar rats treated with $T$. impetiginosa extract.

\begin{tabular}{|c|c|c|c|c|c|c|}
\hline \multirow[t]{2}{*}{ Treatments } & \multicolumn{5}{|c|}{ Comet cells } & \multirow[t]{2}{*}{ DNA damage index ${ }^{a}$} \\
\hline & Level 0 & Level 1 & Level 2 & Level 3 & Level 4 & \\
\hline Neg. control & $78.0 \pm 8.7$ & $18.0 \pm 7.4$ & $3.0 \pm 0.8$ & $1.0 \pm 0.8$ & 0 & 27.0 \\
\hline DMSO & $88.3 \pm 7.6$ & $5.8 \pm 1.7$ & $3.8 \pm 4.3$ & $2.3 \pm 2.6$ & 0 & 20.3 \\
\hline DXR & $39.8 \pm 8.1$ & $22.8 \pm 5.8$ & $17.8 \pm 7.7$ & $11.8 \pm 5.3$ & $8.0 \pm 2.9$ & $125.8^{\mathrm{b}}$ \\
\hline TI 100 & $44.2 \pm 30.7$ & $28.2 \pm 14.5$ & $21.2 \pm 30.1$ & $3.8 \pm 4.6$ & $2.6 \pm 4.0$ & 92.4 \\
\hline TI 300 & $22.4 \pm 13.0$ & $43.2 \pm 9.3$ & $26.0 \pm 9.7$ & $5.4 \pm 6.0$ & $3.0 \pm 4.1$ & $123.4^{\mathrm{b}}$ \\
\hline TI 500 & $33.0 \pm 12.5$ & $31.8 \pm 14.3$ & $14.4 \pm 5.4$ & $10.6 \pm 5.4$ & $10.2 \pm 3.5$ & $133.2^{\mathrm{b}}$ \\
\hline
\end{tabular}

${ }^{a}$ DNA damage Index $=\left(0 \times \mathrm{n}_{0}\right)+\left(1 \mathrm{xn}_{1}\right)+\left(2 \mathrm{xn}_{2}\right)+\left(3 \mathrm{xn}_{3}\right)+\left(4 \mathrm{x} \mathrm{n}_{4}\right)$, where $\mathrm{n}=$ number of cells at the corresponding level of DNA damage $(0-4)$. bsignificantly different when compared to negative control $(\mathrm{p}<0.05)$.

$\mathrm{DXR}=90 \mathrm{mg} \mathrm{kg}^{-1}$ b.w.; DMSO $=10 \%$; TI: Tabebuia impetiginosa extract $\left(\mathrm{mg} \mathrm{kg}^{-1}\right.$ b.w. $)$.

Table 2 - Distribution of comet cells (mean \pm SD) and DNA damage index in liver cells of Wistar rats treated with T. impetiginosa extract.

\begin{tabular}{|c|c|c|c|c|c|c|}
\hline \multirow[t]{2}{*}{ Treatments } & \multicolumn{5}{|c|}{ Comet cells } & \multirow[t]{2}{*}{ DNA damage index ${ }^{a}$} \\
\hline & Level 0 & Level 1 & Level 2 & Level 3 & Level 4 & \\
\hline Neg. control & $66.3 \pm 5.3$ & $22.3 \pm 6.8$ & $7.8 \pm 3.0$ & $2.8 \pm 1.0$ & 0 & 46.3 \\
\hline DMSO & $24.0 \pm 11.5$ & $51.0 \pm 11.7$ & $15.0 \pm 0.8$ & $9.0 \pm 5.0$ & $1.0 \pm 1.2$ & 112.0 \\
\hline DXR & $33.5 \pm 9.0$ & $19.5 \pm 5.4$ & $11.8 \pm 5.4$ & $26.3 \pm 6.8$ & $9.0 \pm 2.8$ & $158^{\mathrm{b}}$ \\
\hline TI 100 & $27.8 \pm 18.2$ & $31.2 \pm 6.8$ & $16.4 \pm 10.7$ & $14.8 \pm 8.1$ & $9.8 \pm 9.0$ & $147.6^{\mathrm{b}}$ \\
\hline TI 300 & $14.8 \pm 13.2$ & $32 \pm 10.4$ & $28.4 \pm 14.0$ & $22 \pm 7.1$ & $2.8 \pm 2.7$ & $166.0^{\mathrm{bc}}$ \\
\hline TI 500 & $9.8 \pm 9.6$ & $22.2 \pm 17.3$ & $13.2 \pm 2.2$ & $37.2 \pm 24.2$ & $17.6 \pm 7.9$ & $230.6^{\mathrm{bd}}$ \\
\hline
\end{tabular}

${ }^{a}$ DNA damage Index $=\left(0 \times n_{0}\right)+\left(1 \mathrm{xn}_{1}\right)+\left(2 \mathrm{xn}_{2}\right)+\left(3 \mathrm{xn}_{3}\right)+\left(4 \mathrm{xn}_{4}\right)$, where $\mathrm{n}=$ number of cells at the corresponding level of DNA damage $(0-4)$. 'significantly different when compared to negative control $(\mathrm{p}<0.05)$.

${ }^{\mathrm{c}} 0.001<\mathrm{p}<0.01$.

${ }^{\mathrm{d}} \mathrm{p}<0.001$.

$\mathrm{DXR}=90 \mathrm{mg} \mathrm{kg}^{-1}$ b.w.; DMSO $=10 \%$; TI: Tabebuia impetiginosa extract $\left(\mathrm{mg} \mathrm{kg}^{-1}\right.$ b.w.). 
Frequency of different levels of DNA damage in blood and liver comet cells

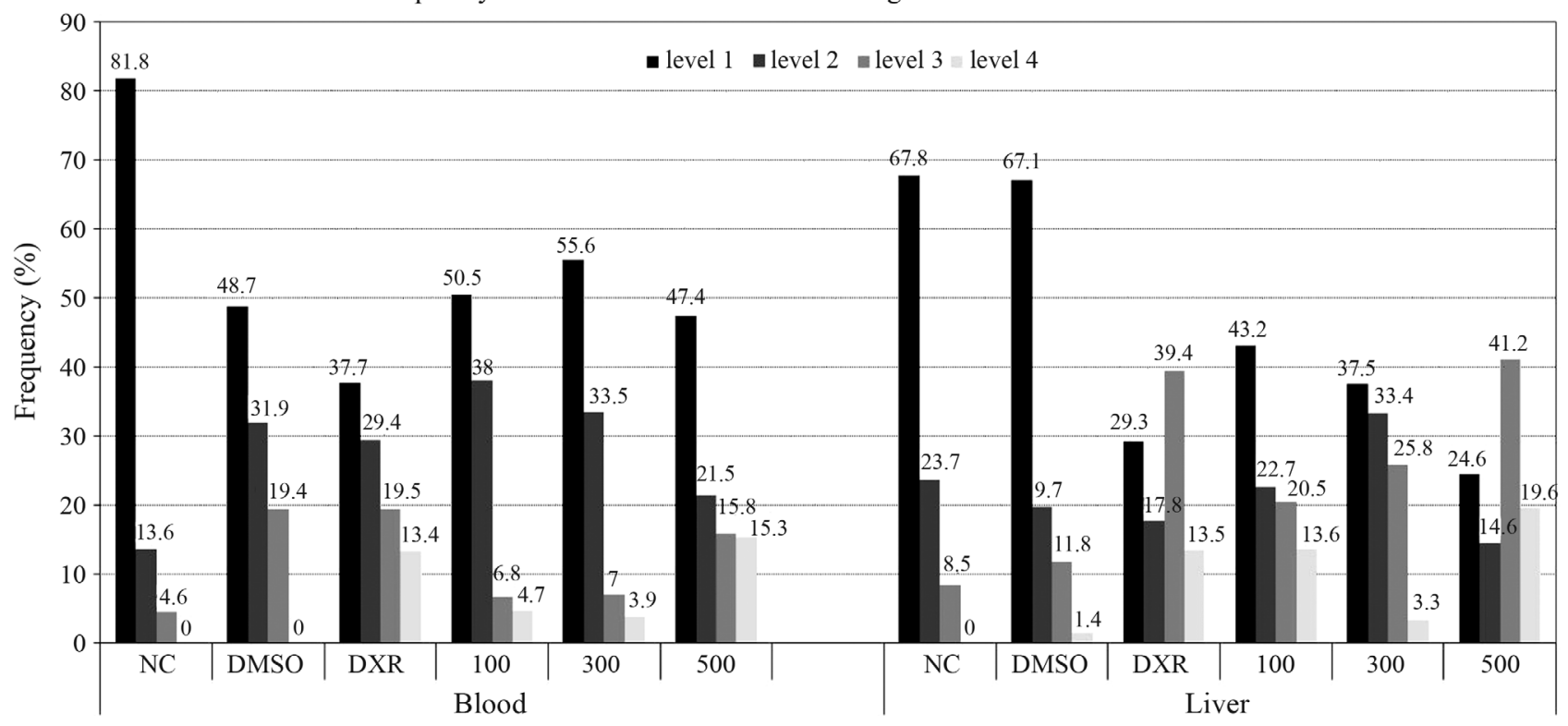

Figure 1 - Distribution of comet cells according to the level of DNA damage detected in blood and the liver. Nucleoids in class 0, i.e., no DNA damage, were not shown. NC: negative control; DMSO: solvent control; DXR: doxorubicin at $90 \mathrm{mg} \mathrm{kg}^{-1}$ b.w.; Tabebuia impetiginosa extract at 100, 300 and $500 \mathrm{mg} \mathrm{kg}^{-1}$ b.w.

in vivo by way of comet assaying, a quick, simple and highly sensitive method for detecting single and double DNA strand breaks and alkali-labile sites under conditions of exposure to a chemical or physical compound with genotoxic potential (Gontijo and Tice, 2003; Kumaravel and Jha, 2006). During the battery of assays for genotoxic evaluation, it is important to include negative, positive and solvent control groups (Tice et al., 2000). One of the most important advantages of the comet assay is its applicability to various tissues and organs simultaneously, through independence of cell division for revealing the extent of DNA damage (Tice et al., 2000; Hartman et al., 2003). In the present study, the genotoxic potential of a T. impetiginosa extract on liver and blood cells was evaluated. As the liver is the preeminent organ in metabolization, according to the different protocols for comet assaying in vivo, analysis of its cells is recommended (Tice et al., 2000; Hartman et al., 2003). Even so, in the present study, blood cells were also used, through representing a potential target for genotoxic compounds, independent of the parameter considered for analysis (Groover et al., 2001; Rodeiro et al., 2006).

The analysis of liver and blood cells at $24 \mathrm{~h}$ after treatment revealed highly extensive DNA damage when compared to the negative control, the effect being more pronounced in the former. Post analysis of the genotoxic effects of Stevia, a naturally sweeter compound extracted from Stevia rebaudiana, also revealed higher levels of DNA damage in the liver than in other tissues such as the brain, spleen and blood (Nunes et al., 2007). The genotoxic and antigenotoxic effects of T. impetiginosa were evaluated with the Somatic Mutation and Recombination Test (SMART) (De Sousa et al., 2009). These authors had previ- ously noted that the plant, although not genotoxic in itself, was so through potentially inducing DXR genotoxicity. They also evaluated the antigenotoxic effects, without finding any significant results. The methanolic extract of the plant, especially the chloroform fraction, was capable of attenuating platelet aggregation and vascular smoothmuscle-cell proliferation, probably through the suppression of arachidonic acid liberation and ERK1/2 MAPK activation (Son et al., 2006).

In the present case, collection was $24 \mathrm{~h}$ after treatment with the $T$. impetiginosa extract, as previously recommended for in vivo comet assaying (Tice et al. (2000). In a previous study, an increase in DNA damage had been detected by comet 3,24 and $48 \mathrm{~h}$ after treatment in various organs, this including blood and the liver (Gary et al., 2003). Even so, the maximum DNA damage was observed after intermediate exposure of $24 \mathrm{~h}$ in all the tested organs. Irrespective of the high level of DNA damage in the blood and liver cells encountered here, the mechanisms involved are unrecognizable. It is well known that $T$. impetiginosa is a naturally occurring source of naphthoquinones, previously extensively described by way of their genotoxic activities, through the generation of reactive oxygen species, inhibition of topoisomerase II and activation of topoisomerase I (Boothman et al., 1989; Klaus et al., 2010).

According to the findings presented here, $T$. impetiginosa extract presented high genotoxic activity in Wistar rats, whereby its use in alternative medicine requires caution. Further in vivo investigation is proposed to elucidate the mechanisms by which this compound induces genotoxic consequences. 


\section{References}

Abbott BJ, Hartwell JL, Leiter J, Perdue Jr RE and Schepartz SA (1967) Screening data from the Cancer Chemotherapy National Service Center screening laboratories. XL. Plant extracts. Cancer Res 27:190-345.

Aruoma OI (2003) Methodological considerations for characterizing potential antioxidant actions of bioactive components in plant foods. Mutat Res 523:9-20.

Boothman DA, Trask DK and Pardee AB (1989) Inhibition of potentially lethal DNA damage repair in human tumor cells by $\beta$-lapachone, an activator of topoisomerase I. Cancer Res 49:605-612.

Burlinson B, Tice RR, Speit G, Agurell E, Brendler-Schwaab SY, Collins AR, Escobar P, Honma M, Kumaravel TS, Nakajima M et al. (2007) Fourth international workshop on genotoxicity testing: Results of the in vivo comet assay workgroup. Mutat Res 627:31-35.

Collins AR, Oscoz AA, Brunborg G, Gaivão I, Giovannelli L, Kruszewski M, Smith CC and Stetina R (2008) The comet assay: Topical issues. Mutagenesis 23:143-151.

De Sousa NC, de Rezende AA, da Silva RM, Guterres ZR, Graf U, Kerr WE and Spanó MA (2009) Modulatory effects of Tabebuia impetiginosa (Lamiales, Bignoniaceae) on doxorubicin-induced somatic mutation and recombination in Drosophila melanogaster. Genet Mol Biol 32:382-388.

Gontijo AMMC and Tice R (2003) Comet Assay for detection of DNA damage and repair in individual cells. In: Ribeiro LR, Salvadori DMF and Marques EK (eds) Mutagênese Ambiental. ULBRA Inc., Canoas, pp 247-275.

Gary S, Nesslany F, Aliouat E, Haguenoer JM and Marzin D (2003) Assessment of genotoxic effect of benzo[a]pyrene in endotracheally treated rat using comet assay. Mutat Res 534:33-43.

Groover P, Banu BS, Devi KD and Begum S (2001) In vitro genotoxic effects of mercuric chloride in rat peripheral blood leukocytes using comet assay. Toxicology 167:191197.

Hartmann A, Agurell E, Beeyers C, Brendler-Schwaab S, Burlinson B, Clay P, Collins A, Smith A, Speit G, Thybaud V et al. (2003) Recommendations for conducting the in vivo alkaline comet assay. Mutagenesis 18:45-51.

Itokawa H, Morris-Natschke SL, Akiyama T and Lee K (2008) Plant derived natural product research aimed new drug discovery. J Nat Med 62:263-280.

Klaus V, Hartmann T, Gambini J, Graf P, Stahl W, Hartwig A and Lars-Oliver K (2010) 1,4-Naphthoquinones as inducers of oxidative damage and stress signaling in HaCaT human keratinocytes. Arch Biochem Biophys 496:93-100.

Koyama J, Morita I, Tagahara K and Hirai KJ (2000) Cyclopentene dialdehydes form Tabebuia impetiginosa. Phytochemistry 53:869-872.
Kumaravel TS and Jha AN (2006) Reliable comet assay measurements for detecting DNA damage induced by ionising radiation and chemicals. Mutat Res 605:7-16.

Liao W, McNutt MA and Zhu WG (2009) The comet assay: A sensitive method for detecting DNA damage in individual cells. Methods 48:46-53.

Melo JG, Santos AG, Amorim ELC, Nascimento SC and Albuquerque UP (2011) Medicinal plants used as antitumor agents in Brazil: An ethnobotanical approach. Evid Based Complement Alternat Med 365359.

Nunes AP, Ferreira-Machado SC, Nunes RM, Dantas FJ, De Mattos JC and de Araújo AC (2007) Analysis of genotoxic potentiality of stevioside by comet assay. Food Chem Toxicol 45:662:666.

Park BS, Lee HK, Lee SE, Piao XL, Takeoka GR, Wong RY, Ahn YJ and Kim JH (2006) Antibacterial activity of Tabebuia impetiginosa Martium ex DC (Taheebo) against Helicobacter pylori. J Ethnopharmacol 105:255-262.

Rodeiro I, Cancino L, Gonzaléz JE, Morffi J, Garrido G, Gonzaléz RM, Nuñez A and Delgado R (2006) Evaluation of the genotoxic potential of Mangifera indica L. extract (Vimang), a new natural product with antioxidant activity. Food Chem Toxicol 44:1707-1713.

Santos RA, Cabral TR, Cabral IR, Antunes LMG, Andrade CP, Cardoso PCS, Bahia MO, Pessoa C, Nascimento JLM, Burbano RR et al. (2008) Genotoxic effect of Physalis angulata L. (Solanaceae) extract on human lymphocytes treated in vitro. Biocell 32:195-200.

Sharma PK, Khanna RN, Rohatgi BK and Thomson RH (1988) Tecomaquinones III: A new quinone from Tabebuia pentaphylla. Phytochemistry 27:632-633.

Singh NP, McCoy MT, Tice RR and Schneider EL (1988) A simple technique for quantitation of low DNA levels of DNA damage in individual cells. Exp Cell Res 175:184-191.

Skalani A and Kutty SK (2008) Plant-derived compounds in clinical trials. Drug Discov Today 13:161-171.

Son DJ, Lim Y, Park YH, Chang SK, Yun YP, Hong JT, Takeoka GR, Lee KG, Lee SE, Kim MR et al. (2006) Inhibitory effects of Tabebuia impetiginosa inner bark extract on platelet aggregation and vascular smooth muscle cell proliferation though suppressions of arachidonic acid liberation and ERK1/2 MAPK activation. J Ethnopharmacol 108:148-151.

Tice RR, Agurell E, Anderson D, Burlinson B, Hartmann A, Kobayashi H, Miyamae Y, Rojas E, Ryu JC and Sasaki, YF (2000) Single gel/comet assay: Guidelines for in vitro and in vivo genetic toxicology testing. Environ Mol Mutagen 35:206-221.

Zani CL, de Oliveira AB and de Oliveira GG (1991) Furanonaphthoquinones from Tabebuia ochracea. Phytochemistry 30:2379-2381.

Daisy M.F. Salvadori

License information: This is an open-access article distributed under the terms of the Creative Commons Attribution License, which permits unrestricted use, distribution, and reproduction in any medium, provided the original work is properly cited. 